Language in Africa 1(3), 2020, 125-154. doi: 10.37892/2686-8946-2020-1-3-125-154

\title{
PLURALITY MARKING IN LEKO AND YENDANG GROUPS (ADAMAWA, NIGER-CONGO) WITH SOME REFERENCE TO NOUN CLASSIFICATION
}

\begin{abstract}
Alexander Zheltov
St. Petersburg State University / Museum of Anthropology and Ethnography RAS

ajujeltov@mail.ru
\end{abstract}

Abstract: The article presents the available data about plurality marking in two groups (Leko and Yendang) of a hypothetical genetic unit known as Adamawa languages. It shows various strategies that languages of these two groups use in marking plurality. The main focus is made on Nyong and Maya (Bali) languages with which the author worked during field research in Adamawa state (Nigeria). The data of some other languages of these groups (Samba Leko, Kpasham (Sam), Kugama (Wam), Yendang and Waka) are also taken into consideration. This study offers a comparison of plurality strategies in these languages that helps in distinguishing conservative and innovative elements in plurality marking. It also shows some cases of possible plurality/noun class interaction.

Key words: Adamawa, Leko languages, Yendang languages, plurality, number, noun classification

\section{Introduction. Some remarks about genetic affiliation}

"Adamawa" is one of the most disputable units within the Niger-Congo macrofamily. The formerly used (since Greenberg 1963) wider term "Adamawa-Ubangi" (or "Adamawa-Eastern") happened to be rejected. Some language groups of this family tend to be compared with Gur languages, some others appear to have common features with Benue- 
Congo. ${ }^{1}$ There are various versions of the classification of Adamawa languages: (Greenberg 1963; Bennet 1983; Boyd 1989; Blench 2004; 2012; 2020; Lewis et al. 2014; Güldemann 2018; Kleinewillinghöfer 2019; Hammarström et al. 2019); they demonstrate rather substantial differences originated from the lack of data for many of the languages.

This article is not supposed to contribute much to the discussion about genetic affiliation of the Adamawa languages, but some working preliminary lexicostatistic data received during field research are presented in this section. They concern languages of two groups - Leko ${ }^{2}$ (marked as Group 2 in (Greenberg 1963), Group 8 in (Blench 2020) and including Leko (Leeko), Nyong (Mumbake), Kolbila, Perema), and Yendang $^{3}$ (Mumuye-Yendang - marked as Group 5 in (Greenberg 1963), Group 6 in (Blench 2020) and including Yendang (with Kusheki, Yoti), Waka, Bali (Maya), Kpasham (Sam), Teme, Kumba (Sate, Yofo), Gengle, Kugama (Wam)). ${ }^{4}$ In case of the Leko (Sambaic) group two languages are under consideration - Samba Leko and Nyong, the latter being more in focus as the author worked with it during his field work. We can be sure about their rather close relations which are supported by lexicostatistics (see Table 1). These languages have about $65 \%$ of common roots from the Swadesh list, and the speakers of Nyong consider Samba

${ }^{1}$ Ulrich Kleinewillinghöfer and Dmitry Idiatov with Mark van der Velde presented some arguments in favor of these connections at the First Adamawa Conference in Mainz, September 2019.

${ }^{2}$ Leko languages are a part of the larger group called Samba-Duru (Kleinewillinghöfer 2015; Güldemann 2018: 200, 207-208). The reviewer proposes to call this sub-group "Sambaic" following (Hammarström et al. 2019). However, the existence of different (and not related, see Bennet 1983) Samba Daka language makes this name confusing.

${ }^{3}$ Yendang languages are often considered to be a part of the larger group called Mumuye-Yendang (Greenberg 1963; Blench 2000), but in (Güldemann 2018; Kleinewillinghöfer 2019) these groups are considered separately. The reviewer proposes to call this sub-group "Yendangic" to avoid the confusion with the language name.

${ }^{4}$ See Appendix 2 for classificational tree of Central Adamawa, the group all these languages belong to. 
Leko speakers as a culturally close ethnic group. The composition of the Yendang group appears to be supported by lexicostatistics as well, showing about $40-60 \%$ of cognates. Yendang is closer to Waka (75\%) and Maya to Kpasham (78\% for 200 -word list, see Table 2). In this article, I deal mostly with Maya (Bali), while including some data from Yendang, Kugama (Wam), Waka and Kpasham (Sam).

Table 1

\section{Lexicostatistics (100-word list)}

of some Leko (marked in bold) and Yendang languages ${ }^{5}$

\begin{tabular}{|l|c|c|c|c|c|c|c|}
\hline $\begin{array}{c}100 \\
\text { word list }\end{array}$ & Waka & Yendang & $\begin{array}{c}\text { Maya } \\
\text { (Bali) }\end{array}$ & Teme & Gengle & Kumba & $\begin{array}{c}\text { Samba } \\
\text { Leko }\end{array}$ \\
\hline Yendang & 75 & & & & & & \\
\hline Maya (Bali) & 50 & 49 & & & & & \\
\hline Teme & 63 & 60 & 49 & & & & \\
\hline Gengle & 51 & 50 & 52 & 48 & & & \\
\hline Kumba & 43 & 43 & 39 & 42 & 41 & & \\
\hline Nyong & $\mathbf{2 4}$ & $\mathbf{2 4}$ & $\mathbf{2 5}$ & $\mathbf{2 6}$ & $\mathbf{2 4}$ & $\mathbf{2 1}$ & $\mathbf{6 5}$ \\
\hline
\end{tabular}

Table 2

Maya, Kpasham, and Nyong 200-word list statistics ${ }^{6}$

\begin{tabular}{|l|c|}
\hline \multicolumn{1}{|c|}{$\mathbf{2 0 0}$ word list } & Maya (Bali) \\
\hline Nyong & $13 \%$ \\
\hline Kpasham (Sam) & $78 \%$ \\
\hline
\end{tabular}

${ }^{5}$ For Maya and Nyong I used my own field data; for Waka and Yendang the data are from the field work of Anastasia Lyahovich and Tatiana Anikina correspondingly; for Samba Leko the data come from the dictionary in (Fabre 2004); for Teme, Gengle and Kumba I used the word lists of the Panlex project (http://panlex.org/, date of application 08.05.2012). It is worth noting that these data are very preliminary and are based on impressionistic comparison of word lists rather than strict sound correspondences or automatic program.

${ }^{6}$ The data are from my field work. 
The relations between Leko and Yendang groups are also evident, although much more distant (about 25\% between Nyong and some Yendang(ic) languages, see Table 1).

\section{Data}

The data on Nyong (ISO 639-3-muo) and Maya (ISO 639-3-ben) which are in the focus of this article were collected during three one-month long field trips to Yola (Adamawa province, Nigeria) in 2012-2014. ${ }^{7}$ It is worth noting that the data presented in the article are very preliminary: problems with transcription are far from being resolved, it is still more phonetic than phonological, the tonal notation needs to be specified, lexical data are not very rich and not all grammatical rules and processes are clear. These data and the analysis presented in this article, however, are likely to be the first documentation of the languages under consideration. ${ }^{8}$

The Nyong language is spoken in Cameroon and Nigeria in two non-contact enclaves. The work was carried out with two language assistants, brothers Jonathan and Solomon Conleganyiga, and dealt with Nigerian Nyong. The total number of speakers can be estimated as several thousand (for Nigeria, excluding Cameroon), and the center of Nyong people in Nigeria appears to be located in Mumbake village where the initiation procedure for all Nigerian Nyongs takes place.

Maya is a common name for a dialect cluster whose area includes two dozen localities to the West of Yola, the largest of which is Bali. The name of this locality is used in some survey papers as the language name (Blench 2020). Yeti and Kpasham, also sometimes included in

${ }^{7}$ These trips were sponsored by the research grant of St. Petersburg State University, No. 2.38.524.2013.

${ }^{8}$ There is one phonological survey of Cameroonian Nyong (not Nigerian) (Kouonang 1983). For Maya (Bali) the only references are (A guide... 2007; Blench 2009). 
Maya, should be considered separate languages. According to my language assistants Zenon Joel and Dauda Martin, the language differences between the dialects of other localities are rather little. The term Maya is used to combine the variants of all localities and was preferred by informants over the term Bali. The choice of this name can be connected with the activity of translating the Bible and an attempt to develop a single literary norm.

The data of Samba Leko (ISO 639-3- ndi) were taken from a grammar by Fabre (2004). ${ }^{9}$ The data of Yendang (ISO 639-3-inq), Wam (Kugama) (ISO 639-3-kow) and Waka (ISO 639-3-wav) were collected during the same field trips by my colleagues Tatiana Anikina (Anikina 2012), Lora Litvinova (Litvinova 2016) ${ }^{10}$ and Anastasia Lyahovich (personal communication) ${ }^{11}$ correspondingly. As for Sam (Kpasham) (ISO 639-3-pbm) data, I used the presentation by Eveling Villa (Villa 2017).

The choice of languages of these two groups as an object for analyzing plurality marking in this article is not based only on the field experience of the author and the colleagues from the same team. The languages of Leko and Yendang groups share an important feature distinguishing them from many Niger-Congo families and some other groups of Adamawa languages as well (e.g. Yungur):

${ }^{9}$ It is worth noting that this is the only fundamental published description of the languages under consideration, for the other languages the data are preliminary and often not published.

${ }^{10}$ Lora Litvinova after her first trip to Nigeria in 2014 continued her field work as a PhD student of LLACAN (Paris) and shared with me some new data on nominal morphology in Kugama in personal communication. I introduced some changes into Kugama data according to her comments on my presentation about this topic at the first Adamawa Conference in Mainz, September 2019. I am very grateful to her for this consultation.

${ }^{11}$ She has not published her data about plurality in Waka yet, but shared and commented her field notes about plurality in Waka (for which I am very grateful). It was not sufficient for making a special section, but allowed me to include some Waka data into comparative tables. 
they have practically no noun classes. ${ }^{12}$ This fact makes plurality marking very important for discovering at least some elements of noun classification. This common typological feature creates the basis for presenting the comparative observation of plurality marking in these two groups.

\section{Theoretical background}

In linguistic typology, the category of number is often considered as rather simple comparing to such categories as case or noun class/gender. Indeed, a superficial look at the expression of plurality in different languages leads to a fairly clear picture: the singular is often not marked, and the plural has a special universal marker for all names, as in the case of English $-s$ or Turkish -lAr. The singular marker can vary according to gender (noun class), and in plural the gender cannot be distinguished, as in Russian and many other Indo-European languages. The presence of a dual number in some languages (as well as "triple" and "paucal", as in some Papuan languages, see Foley 1986) does not fundamentally complicate the morphosyntactic characteristics of number. However, a serious analysis of the morphosyntactic characteristics of the category shows that number is an interesting and diverse category. As Greville Corbett states in his monograph, "number is the most underestimated of the grammatical categories. It is deceptively simple and is much more interesting and varied than most linguists realize" (Corbett 2000: 1).

The Niger-Congo languages demonstrate a great variety in morphosyntactic characteristics of number. At first glance, number in many languages refers to two types: a uniform marking of number only in the plural (Mande - similar to English); the distinction is complicated by gender/class (Bantu - similar to Russian). However, number in Mande and in Bantu is fundamentally different from number in English and Russian and refers to different typological classes. In

${ }^{12}$ About noun classes and plurality in other groups of Adamawa see, for instance, (Kleinewillinghöfer 1992; van de Velde \& Idiatov 2017). 
Mande, the plurality clitics ${ }^{13}$ mark the whole NP and can occur either on the noun or on dependent constituents (but only once), and disappear when lexical pluralizers (numerals, 'many') are used, which is quite different from English-like plurality. In Bantu, noun class distinctions are not neutralized in the plural, Bantu languages having several plural classes, comparing to just one in a language like Russian.

In addition, number and class are often syncretic categories in Niger-Congo, and these syncretic class/number affixes are important for historical-comparative studies of Niger-Congo languages being (together with verbal extensions) an important argument in favor of the existence of this macrofamily (Güldemann 2018).

Taking into account the problematic position of Adamawa languages within Niger-Congo, the analysis of the ways they use to mark plurality seems to be of great importance. The languages of the Leko and (especially) Yendang groups are among the least studied even among the Adamawa languages. Another consideration is that their nominal morphology is not very rich, and plural markers often are the only possible candidates for the traces of class markers. In the following sections I present some preliminary analysis of plurality marking in the afore-mentioned languages in connection with noun classification and possible agreement. Namely, Leko and Yendang languages tend to demonstrate a certain split for animate/inanimate nouns, some elements of the agreement, or marking number only on dependent constituents (adjectives). As it is stated in (Dryer 2013), "there are basically two ways in which languages indicate plurality. The first (and most common) involves changing the morphological form of the noun, as in English dog, dogs. The second involves indicating plurality by means of a morpheme that occurs somewhere else in the noun phrase..." As I will show, the Adamawa languages demonstrate both these ways, and rather often do it within one language.

13 The term "clitics" is used for such kind of morphemes in (Plungian 2011: 70; Vydrin 2017: 62), while in (Mel'čuk 1997: 287) the term "migrating affix" is offered. 


\section{Number in the Leko group}

\subsection{Number in Samba Leko (Fabre 2004: 81)}

There are two ways of marking plurality in Samba Leko:

1) standard pluralizer $b \bar{\partial} d$,

2) suffixed labial consonant for human nouns.

Standard pluralizer is bād: yagād 'dog' yagād bād 'dogs'. It appears to be a lexical unit (plural word) rather than an affix, but its etymology is unclear. The word for 'many' is different. At the same time some plural forms for humans with a final labial consonant are also attested:

nÉy 'person' nÉb 'persons'

kên 'woman' $\sim k \hat{\varepsilon} m$ 'women'

vân 'man' vôm 'men'

wà 'child' yē b 'children'

?̀̀d 'friend' 2̉b 'friends'

These forms can be optionally used with bād. Both néy 'person' and nźb 'persons' can be used as the derivative agentive without plural meaning.

\subsection{Number in Nyong ${ }^{14}$}

In Nyong, there are three ways of marking plural on nouns:

1) -foro, the standard plural marker,

2) -(ri)pa, a plural marker limited to a specific semantic class,

3) suppletion, where the singular and plural form are expressed with different stems.

In Nyong there is a standard plural form -foro. It is combined with all nouns, but for lexemes that have special irregular plural forms (see below), its use is considered not grammatical. The final vowel of the singular form usually falls out: pãyá 'door from cane' pãyforo 'doors

${ }^{14}$ Some elements of Nyong grammar are presented in (Zheltov 2014). 
from cane ${ }^{15}$, sometimes a whole syllable is truncated (in all recorded cases the truncated final syllable is -ra): wãrá 'stream, river' $\sim$ wãforo 'streams, rivers'. It is an argument in favor of considering this form as a suffix rather than a plural word, but this problem is not clear yet.

There is also a suppletive form: wa 'child' - yefera 'children'.

The plural forms with $-p a$ suffix, sometimes having the form of -ripa (e.g. mansa - maysá-ri-pá 'friend - friends'), the -ri- element being facultative in some cases (e.g. bùsá - bùsá-(ri)-pá 'frog - frogs') seems to be of particular interest. They are formed in a limited semantic group of names, including the designations of humans and animals, but animals are almost exclusively domestic. This group includes the following lexemes:

nà 'cow' nà-pá 'cows'

ya 'dog' ya-pá 'dogs'

maysa 'friend' maysá-ri-pá 'friends'

ko 'chicken' ko-pá 'chickens'

vùa 'goat' vù-pá 'goats'

bùsá 'frog' bùsá-(ri)-pá 'frogs'

The suppletive pairing nìdina 'person' $\sim$ nepá 'persons' seems to have the same suffix in the plural. Perhaps the same suffix with some assimilative nasalization should be postulated for the forms nekémmà 'women' (cf. nekénna 'woman') and nevemmà 'men' (cf. nevenna 'man'). However, the low tone of the final syllable in both of these forms witnesses against this interpretation.

Interestingly, this class does not include words for domestic animals with the meaning of 'horses', 'cats', 'ducks', 'pigs', which form the standard plural with -foro, like all wild animals. On the other hand, it is quite puzzling that this class includes bùsá 'frog' bùsá-(ri)-pá 'frogs', suggesting the question, why is a frog more "domestic" than a cat.

${ }^{15}$ The tonal notation is very preliminary. The absence of tone marking indicates middle tone. 
The following semantic justification for this formal class can be offered: it unites people and animals related to the human environment. Cats, ducks, and pigs were not included into this class since they are identified with their wild counterparts and most likely the same word is used for the corresponding wild animals (in the case of 'pig', this is confirmed by the language assistant), while pets whose names fall into the formal class described above do not have wild counterparts that Nyong speakers would identify them with. Horses are evidently strange for Nyong culture and are not treated as "domestic". Getting frogs in the class of "domestic" animals is due to the large number of frogs that live in this area quite close to human habitation, besides, according to the language assistant, they are used for food. Similar proximity to humans (as opposed to wild cats and pigs that do not live near human habitation) and functional analogy (use for food) with other pets "domesticated" frogs for Nyong speakers.

Thus, Nyong demonstrates an interesting "split" in the expression of number according to animacy hierarchy: names with the semantics of "human" have a special marking together with the words for some domestic animals closely related to human life.

We can also observe a sort of verbal agreement for plural pronouns (1)-(2) and nouns (3)-(4).

(1) Yò bé nà-kò

3SG see cow-REF

'He sees a cow.'

(2) Và bé-ri nà-kò

3PL See-PL COW-REF

'They see a cow.'

(3) Bùsá bé nà-kò

frog see cow-REF

'The frog sees a cow.'

(4) Bùsa'-(rí)pá bé-ri nà-kò

frog-PL see-PL cow-REF

'The frogs see a cow.' 
Interestingly, this agreement marker coincides with the -ri- element which is used in nouns (see above), sometimes facultatively (as for 'frog'), or obligatorily (as for 'friend'). ${ }^{16}$

\subsection{Conclusion on the Leko group}

Comparing the plurality in Samba Leko and Nyong we can trace one common feature: labial stops (voiced in case of Samba Leko, unvoiced in case of Nyong) are used for human plural. Nyong keeps also /a/ as a final vowel for this affix. These forms seem to be the remnant of a possible human plural class which can be compared with the human plurality marker in many Niger-Congo languages. ${ }^{17}$ Regular plural forms bə̄d (Samba Leko) and -foro (Nyong) look like recent innovative elements. It is also worth noting that according to the preliminary analysis of Wom (Perema) (which seems to be the closest relative of both Nyong and Samba Leko) plurality marking, according to (Blench 2000), shows similar features, especially with Nyong, including the labial stop for human plurals. ${ }^{18}$

\section{Number in the Yendang group}

\subsection{Number in Maya ${ }^{19}$}

There are four ways of expressing plural in Maya:

(1) some plurals are formed with an $-a$ suffix on the noun,

(2) more frequently, plurals are formed with a suffix $-a$ on attributive modifiers,

${ }^{16}$ An anonymous reviewer mentions (with reference to Elders 2000: 392ff.) that "in Mundang, an Adamawa language spoken in Cameroon and Chad, a similar system is found: the nominal plural marker $-r \bar{a}$ is also found as plural agreement suffix/clitic rá on verbs".

${ }^{17}$ For instance, $b \varepsilon$ for Proto-Atlantic (Pozdniakov 2015: 76), ba for ProtoBenue-Congo (de Wolf 1971: 155).

${ }^{18}$ The Perema data are just mentioned here, as the article I refer to (Blench 2000) presents a preliminary analysis and has a remark "not to be quoted without permission".

${ }^{19}$ Some elements of Maya grammar are presented in (Zheltov 2016). 
(3) there is a singular (6i-) and a plural (zi-) diminutive marker,

(4) some plurals are suppletive.

For most Maya nouns, the singular and plural forms of the noun do not differ: soo 'basket/baskets'. The quantifier kàm 'many' can be added (according to the language assistant, this is a modern form, previously the word gúnì with the same meaning was used). In the Maya wordlist published on the website of Roger Blench (Blench $2013)^{20}$ we can find some regular pairings which seem to form regular plural with -rò:

pàrám 'forehead' pòrò 'foreheads'

té 'ear' térò 'ears'

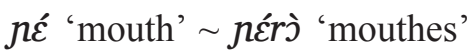

tón 'father' tónrì 'fathers'

nón 'mother' nóro 'mothers'

At first glance, we are dealing with a regular plural, but the lexical semantics of words with these forms (body part terms and kinship terms - a group of words with relative semantics) leads to a completely different interpretation. In all the forms of this "pseudoplural" there is a fused possessive pronoun, according to my transcription -rò 'our' (with a glottalized stop at the end; the openness of the $/ 0 /$ is tentatively represented as positional-phonetic, not phonological). As for singular forms, the vocabulary forms are given, except for the form param, which is most likely to be translated 'my forehead' (cf. ú 'head', úm 'my head'). It is body part terms and kinship terms that are typologically most commonly used with possessives, and it is with them that Maya nouns merge with possessive pronouns (cf. these forms with the words with autosemantic meaning: soo dìm 'my basket/s', soo derò ${ }^{2}$, 'our basket/s' with independent, non-affixed possessive pronouns).

${ }^{20}$ Along with a very brief brochure on the Maya language prepared during the workshop on spelling development for this language (A Guide...2007), this list is the only source of data known to the author about the Maya language. 
At the same time, there are several plural forms in Maya (usually names of humans) formed by an $-a$ suffix, which is sometimes accompanied by assimilative or dissimilative changes in the basic root: $\eta s e ́(e)$ 'woman' ysià 'women' (regressive dissimilation $-\mathrm{e}+\mathrm{a}>\mathrm{ia}$ ), $b i$ 'man' p6ià 'men', wen 'person' $\sim$ wanà 'people' (regressive assimilation - wen $+\mathrm{a}>$ wana).

There is also a special model for diminutives, where the prefix $6 i$ (sometimes pronounced as $6 z^{21}$ ) is used for singular, and $z i$ - for plural: bi-see 'daughter' $\sim$ zi-sià 'daughters' from $\eta s e ́(e)$ 'woman' $\sim$ ysià 'women',

bi-bii 'son' zi-bià 'sons' from $\eta 6 i ́$ 'man' $p 6 i a ̀$ 'men', $6 i-6 e$ 'small goat' $\sim z i-6 e$ 'small goats' from $6 e$ 'goat' / 'goats'.

The model is fairly regular. Possibly ba 'child' zàà 'children' with secondary diminutives bəba 'small child' zizàà 'small children' also belong to this model.

With more regularity, the plural is expressed in Maya not in the head nouns, but in dependent attributes:

ysee gelee 'big woman' psi(a) gel-a 'big women', wen gelee = ygelee 'big person' $\sim$ wan- $a$ gel- $a$ 'big persons' (in the plural a morphological nominalizer was not found).

Moreover, this model also works for other nouns - those that do not have a plural marking in the head noun:

ti gele 'big tree' $\sim$ ti gel-a 'big trees'.

The gele-form can be both an adjective and a qualitative verb. ${ }^{22}$ However, in a predicative function, unlike an attributive one, the forms of the gele type do not have any plural marker (5).

${ }^{21}$ At the moment it is hard to say if it is an optional or a positional variant.

${ }^{22}$ As a qualitative verb it is used as a predicate of qualitative constructions without a copula and with verbal pronouns, rather than independent pronouns, which are used in nominal predication. 
(5) ysee a gelee

woman $3 \mathrm{sg}$ big

'A woman is big.'

(6) $\mathrm{ysi}(\mathrm{a}) \mathrm{ni}$ gelee

women 3PL big

'Women are big.'

It is possible that number marking is blocked by the presence of the corresponding pronoun of verbal series which can already contain plurality in its semantics.

Thus, the Maya language has a special type of plurality marking, in which the most regular marking is observed in the attributive agreement, while just a small number of nouns with human semantics can mark plurality on the head noun. However, it is worth mentioning that a much bigger lexical corpus must be taken into consideration.

\subsection{Number in Kpasham (Sam) (Villa 2017) ${ }^{23}$}

Plural in Kpasham can be expressed:

1) with the plural suffix -á for humans,

2) with the plural prefix zá- for kinship terms,

3) with the plural prefix gún-,

4) with irregular and suppletive forms.

We can find some common features between Sam and Maya (which can be expected if taking into account their close genetic relationship according to lexicostatistics): -á plural suffix for humans, zá- plural prefix and gún- as a regular pluralizer (though in Maya it is regarded by speakers as outdated, and is not used) and quite a few nouns without special plural form (e.g. body parts).

${ }^{23}$ In this section I used the presentation made by Eveling Villa at the 47th Colloquium on African Languages and Linguistics (Leiden, Netherlands), available on the AdaGram site. In her examples, the author uses phonetic transcription which is kept in this article too. 
The plural suffix -á can be realized as $\emptyset \sim-a ́$ pairing, or it can substitute the final vowel of a noun:

tún 'widow' tún-á 'widows',

nj̀bláy 'traveler' nj̀blán-á 'travelers',

nÉsūm 'messenger' лÉsūm-á 'messengers',

wámmáy 'encounter' wámmán-á 'encounters',

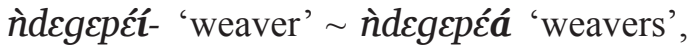

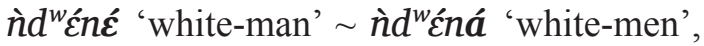

sórć 'fellow-wife' sór-á 'fellow-wives'.

It is not clear if it is possible to include the example ǹs ${ }^{w} \mathcal{E}^{\prime} n u i r^{\prime}$

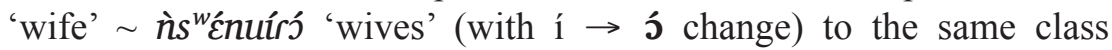
(the pluralizing still makes the vowel more open, but the quality is different).

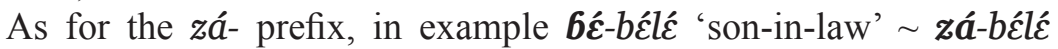
'sons-in-law' it is very similar to Maya examples with $b i-\sim z i$ - pairings for plural marking for animate diminutives bi-bii 'son' zi-bià 'sons'. However, in Sam the meaning of this prefix is not restricted to a diminutive meaning (rather to kinship terms). In examples níná 'mother' zá-níná 'mothers', tùy 'father' zá-tùy 'fathers', s’̀y $\bar{\varepsilon}$ 'sister' $\sim z a ́$-sòy $\bar{\varepsilon}$ 'sisters' there is no diminutive meaning, and the pairing is not $6 \hat{\varepsilon}^{-} \sim z a ́-$, but $\emptyset \sim z a ́-$.

There is another $\mathrm{sg} \sim \mathrm{pl}$ pairing for which we cannot find any analogues

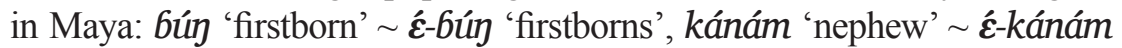
'nephews'. This model also seems to deal with kinship terms.

According to the presented examples, plural with gún-, e.g. gún$6 \bar{\varepsilon} n^{w} \hat{\varepsilon}$ 'flock (of birds)', gún-nàyé 'herd (of cows)', appears to be rather lexical than grammatical as it is evidently derived from gúnì 'crowd'.

In addition, some nouns have irregular plural forms:

wákbĩi 'she-goat' ǹzáwākbî̀̀ 'she-goats', wòn-náá 'rich man' ǹnáá 'rich men', sìáá 'threshing floor' sía 'threshing floors'.

The pair sî́ 'mourning' wúú 'mournings' seems to be suppletive. 


\subsection{Number in Kugama (Litvinova 2016; p.c.)}

Kugama features the following number marking strategies:

(1) suppletion, in three nouns and their derivatives;

(2) the nouns $w \bar{\varepsilon} m$ 'person' and $w \bar{\varepsilon} n \bar{\imath}$ 'people' mark singular and plural for human nouns;

(3) there is a singular (fáà) and a plural (sáà) diminutive marker.

Most of the nouns do not have any morphological plural. Only three words and their derivatives appear to have suppletive forms of plural.

The words $w \bar{\varepsilon} m$ 'person' and $w \bar{\varepsilon} n i$ 'people' are used to mark number distinction of human nouns. These forms, i.e. $w \bar{\varepsilon} m / w \bar{\varepsilon} n \bar{i}$, are involved in compound formation with a simple noun or a verbal noun. These compounds denote professions and occupations: wè $p \bar{\jmath} k \bar{l}$ 'farmer' $w \bar{\varepsilon} n \grave{~} p \bar{\jmath} k \bar{\imath}$ 'farmers' ( $p \bar{\jmath} k \bar{i}$ 'farming') literally 'person/people of farming', wè nóólēy 'soldier' wēnì nóólēy 'soldiers' (nóólēy 'gun').

The modifier ${ }^{24}$ fáà sáà can be analyzed as a diminutive marker: fáà yē6áákā 'small old lady' (yē6áákā 'old lady'). It means "small (in size)" when used with inanimate words: fáà dyéké 'small house' sáà dyéké 'small houses' (dyéké 'house'). When it modifies words such as insects, small and middle-sized animals, it has the meaning of 'child' 'children': fáà dāáa 'lamb' sáà dāáá /lambs' (dāáa 'sheep'). It means 'young' in following examples: fáà wēvéêri 'boy' sáà

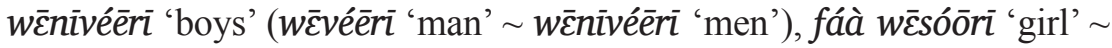
sáà wēnisóōrī 'girls' (wēsóōrī 'woman' wēnissóōrī 'women'). There are few kinship terms which include fáà sáà. In this case, the meaning of the noun is 'younger': fáà nj̄̄̄ki 'younger daughter', fáà tē6áámē 'mother's younger brother', fáà sèn $\bar{\varepsilon}$ 'father's (younger?) brother'.

The noun váa 'child' has a suppletive plural form: sizááa 'children'. These forms are also used in compounding, and therefore they distinguish singular and plural forms of nouns: váà vyépi 'orphan' sìzáà vyépi 'orphans', váa sóōrì 'fiancée' sizzáā sóōrī 'fiancées', etc.

${ }^{24}$ Its morphosyntactic status (word/prefix) is not clear yet. fáà / sáà differ from other nouns like $w \bar{\varepsilon} m$ 'person' $\sim w \bar{\varepsilon} n \bar{\imath}$ 'people', váā 'child' $\sim$ sizáa $\bar{a}$ 'children' in that they cannot be used on their own as a subject or object. 
Another example which can be interpreted as a sort of agreement in Wam is the possessive copula $6 i \grave{i}$ that occurs in a predicate position before a possessor noun or noun phrase. This marker agrees in number with the possessee noun: $6 \grave{i}(\mathrm{SG})(7)$ and $\grave{i}(\mathrm{PL})(8)$.
(7) náákyérē
$6 \grave{\jmath}$
bì
Àlí
COW.DEM.PROX
3SG.NHUM
POSS.SG.COP
Ali
'This cow belongs to (is of) Ali.'
(8)

\begin{tabular}{|c|c|c|}
\hline náákyér̄̄ & $\grave{j}$ & $\grave{\imath}$ \\
\hline COW.DEM.PROX & 3PL.NHUM & POSS.PL.COP \\
\hline
\end{tabular}

\subsection{Number in Yendang (Anikina 2012) ${ }^{25}$}

There are the following plural marking strategies in Yendang:

1) $-i$ suffix,

2) $-r i \sim-t i$ alternation,

3) suppletion.

The most productive form of pluralizing in Yendang is the suffixation of $-i$ with a high tone (sometimes with some morphophonological and tonal changes): ayàba 'banana' ayàbaí 'bananas', tuk? 'ear' tuí 'ears', kún 'bone' kúni 'bones'.

In addition to $-i$ form, $-r i \sim-t i$ alternation is also actively used for plurality marking: e.g. nada-ri 'road' nada-tí' roads'. They do not form any semantic unit (e.g. road, door, pestle, etc.) and are characterized by Tatyana Anikina (Anikina 2012) as a historical alternation.

To refer to people and their professions, Yendang uses a composite form with the initial element $w \varepsilon \eta$, which can be translated as 'person'. The plural of such nouns is formed by adding standard $-i$ suffix to the form $w \varepsilon \eta$, the second part of the composite name does not change: (cf. wèy haki 'peasant' wèyì haki 'peasants').

${ }^{25}$ According to Anastasia Lyahovich (personal communication), plurality marking in Waka is very similar to that of Yendang. 
Yendang also has some suppletive singular/plural pairings (e.g. vaki 'child' $\sim y \varepsilon b \varepsilon$ 'children'). Some nouns traditionally considered in many other languages as Singularia Tantum, can form plurals in Yendang. In this case, an additional expressive value appears: numálore 'rice' numáloríi 'a lot of rice (a lot of plates/bags of rice)'. The plural of some words coincides with their singular form (yànki 'spider' 'spiders', heyyídi 'blacksmith' 'blacksmiths').

The concept of singularity in Yendang is closely related to the category of referentiality and can be expressed by a -bi suffix (takarta$\boldsymbol{b i}$ 'book', $\boldsymbol{l} \boldsymbol{\varepsilon}$-bi 'house', na-bi 'hand'), which occupies the final position in the word. It has a sort of cumulative singular/referential meaning: tà-bi 'one particular monkey' and ta 'some non-specific monkey'. This suffix is not used with demonstratives (9), in presentative (10) and possessive (11) constructions.

(9) takarta $\varepsilon k \varepsilon$

'this book'

(10) $a$ tà

DEM.SBJ monkey

'this is the monkey'

(11) takarta $l \varepsilon \quad$ Ali

POSS Ali book

'book of Ali'.

Another function of $-b i$ is nominalization, in particular, the formation of verbal nouns (e.g. ura 'to run' > urabi 'running').

We can also observe a sort of agreement of a copula (12)-(13).
(12) Ta-bi
$\boldsymbol{b} \boldsymbol{\varepsilon}(k ?)$
bíntày
monkey-SG
COP.SG
big
'Monkey is big'.
(13) $T a-i$
$\boldsymbol{\varepsilon}(k ?)$
bíntàn
monkey-PL
COP.PL
big
'Monkeys are big'. 
For human nouns, similar constructions copulas also agree with the subject in singular (14) and plural (15), but the forms of the copulas are different from non-human nouns.
(14) Wey á bíntày
person.SG COP.SG big
'Person is big.'
(15) Wèn-ì lèn bíntày
person-PL COP.PL big
'Persons are big.'

\subsection{Conclusion on Yendang group}

The presented analysis demonstrates that a substantial part of nouns does not have morphological plural in all the languages of the Yendang group. Maya and Sam share a common feature, that is the $-a$ suffix for the plurality of human nouns. In Maya, it can be regularly observed in adjectival agreement with all the nouns (no data about Sam). The $-a$ suffix is absent in Kugama, Yendang and Waka which, on the other hand, have $-i$ suffix for a few words with various semantics (in Kugama only for 'persons'). In contrast, in Maya, Sam and Kugama there is a subsequent initial alternation of (bi)labial and fricative alveolar consonants as a singular/plural pairing for diminutives (in Kugama only for two words): /G/ / /z/ in Maya and Sam, /f/, /v/ /s/, /z/ in Kugama. Kugama and Yendang have $b(6) \sim \emptyset$ alternation for singular/plural pairing in copulas (in Yendang only for non-human subjects). In Yendang this alternation can be observed for nouns too: ta-bi 'monkey' $\sim$ ta-i 'monkeys'.

\section{Plurality and human-nonhuman distinction in pronouns}

Besides nominal plurality which was analyzed in the previous sections, we can observe the distinctions in number for third person pronouns (see Table 3). 
Table 3

Third person pronouns in some Leko and Yendang languages

\begin{tabular}{|c|c|c|c|c|c|c|}
\hline & Yendang & Waka & Kugama & Maya & Sam & Nyong \\
\hline 3sG Human & 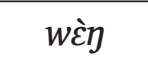 & $\hat{a}$ & $d \varepsilon$ & nyon/a & $a$ & yò \\
\hline $\begin{array}{l}\text { 3sG Non- } \\
\text { human }\end{array}$ & $\varepsilon k^{?}$ & $6 \hat{e}$ & $6 \grave{~}$ & $\begin{array}{c}a u / b i \\
(6 o, b \partial)\end{array}$ & $6 e$ & $\varnothing / y o ̀$ \\
\hline 3PL Human & \multirow[t]{2}{*}{ lદ̀n } & dè & $d i$ & nyón & \multirow[t]{2}{*}{ né } & yá \\
\hline $\begin{array}{l}\text { 3PL Non- } \\
\text { human }\end{array}$ & & $\hat{e}$ & $\grave{j}$ & $\begin{array}{c}a u / b i \\
(6 o, 6 z)\end{array}$ & & $\emptyset$ \\
\hline
\end{tabular}

Analyzing the forms presented in Table 3, we can conclude that all the languages under consideration have human/non-human distinction for third person singular and almost all for third person plural as well (except Yendang and Sam, see Villa 2019). Only Samba Leko (Fabre 2004) does not have any human/non-human distinction in the pronominal system. On the other hand, we can see that Maya and Nyong neutralize number distinction for non-human pronouns, Nyong tending to use a zero form in this context. Waka, Maya and Sam seem to have similar forms for 3sg, human; Waka, Kugama, Maya, and Sam: for 3sg, nonhuman (which looks related to the corresponding nominal affix); Yendang, Waka and Kugama: for 3pl, human.

\section{Conclusion}

In Table $4 \mathrm{I}$ am making an attempt to summarize all the available data on number marking in the languages of Leko and Yendang groups including both general rules and specific patterns. 


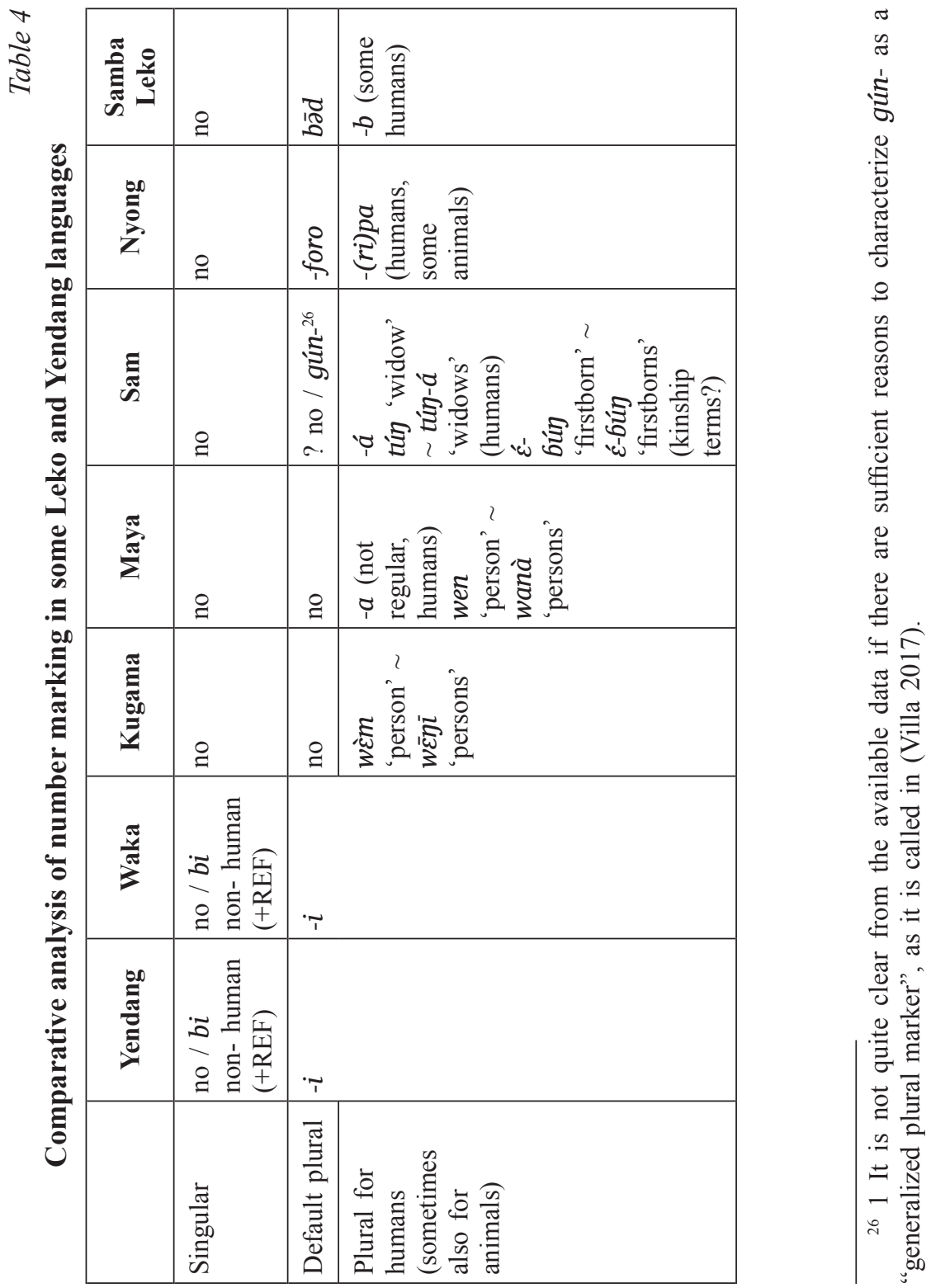




\begin{tabular}{|c|c|c|c|}
\hline 哭 & $\stackrel{\varrho}{\varrho}$ & ๙. & ๙. \\
\hline Z & $\cong$ & 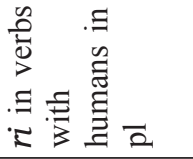 & $\sigma$. \\
\hline 莺 & 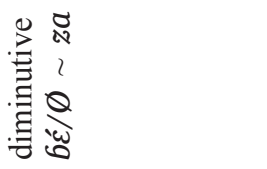 & ๙. & ๙. \\
\hline 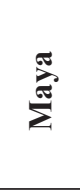 & 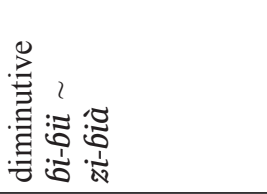 & 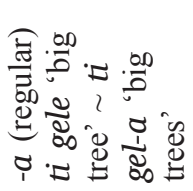 & 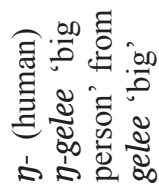 \\
\hline 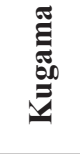 & 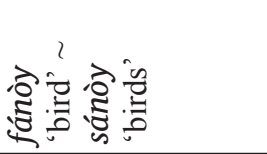 & $\begin{array}{l}\frac{\pi}{\overrightarrow{7}} \\
\frac{0}{0}\end{array}$ & ๙. \\
\hline$\frac{\sqrt[5]{5}}{\sqrt{5}}$ & 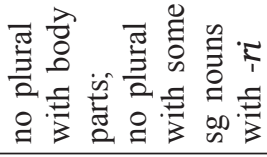 & $\stackrel{\varrho}{\varrho}$ & 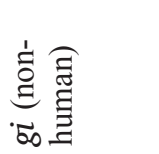 \\
\hline \multirow[t]{2}{*}{ 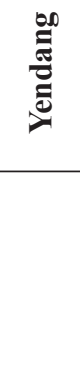 } & 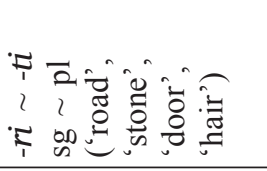 & $\stackrel{\varrho}{\varrho}$ & 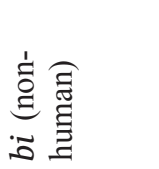 \\
\hline & 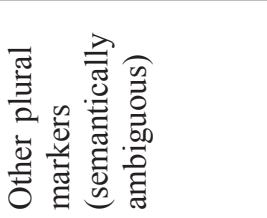 & 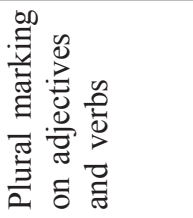 & 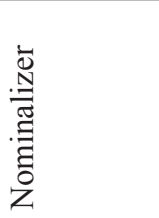 \\
\hline
\end{tabular}


The analysis of the data presented in Table 4 suggests that the languages within the Leko and Yendang groups have much more in common than the languages from different groups.

Comparing the plurality in Samba Leko and Nyong we can trace one common feature, namely that labial stops (voiced in case of Samba Leko, unvoiced in case of Nyong) are used for human plural. Nyong keeps also /a/ as a final vowel for this affix. These forms seem to be the remnant of a possible human plural class which can be compared with the human plurality marker in many Niger-Congo languages (for example, $b \boldsymbol{\varepsilon}$ for Proto-Atlantic (Pozdniakov 2015: 76), $b a$ for ProtoBenue-Congo (de Wolf 1971: 155). It is also worth noting that according to the preliminary analysis of plurality marking in Wom /Perema (which seems to be the closest relative of both Nyong and Samba Leko) (Blench 2000), it has similar features, especially with Nyong, including the labial stop for human plurals.

As for the Yendang group, the substantial part of nouns does not have morphological plural in all the languages of this group. Maya and Sam share the common - $a$ suffix for the plurality of human nouns. In Maya, it can be regularly observed in adjectival agreement with all the nouns (no data about Sam). - $a$ suffix is absent in Kugama, Yendang, and Waka which, on the other hand, have - $i$ suffix for a few words with various semantics (in Kugama only for 'persons'). In Maya, Sam, and Kugama there is an initial alternation of (bi)labial and fricative alveolar consonants as a singular/plural pairing for diminutives (in Kugama only for two words): / $/ / \sim / \mathrm{z} /$ in Maya and Sam, /ff/, /v/ $/ \mathrm{s} /, / \mathbf{z} /$ in Kugama. Kugama, Yendang, and Waka have $b(6) / \varnothing$ alternation for the singular/plural pairing in copulas (in Yendang and Waka only for non-human subjects). In Yendang and Waka this alternation can be observed for nouns too: Yendang ta-bi 'monkey' ta-i 'monkeys'. This analysis confirms a very close relation between Maya and Sam, on the one hand, and Yendang and Waka, on the other hand, Kugama taking some intermediate position.

With this comparison of the languages of different groups we can conclude that there are only two common features among them. First, 
Maya, Sam (Yendang group), Nyong and Perema (Leko group) have a common /a/ vowel for human plurality marking. Taking into account that Samba Leko has a labial stop suffix for some nouns with human semantics and that Nyong and Perema also have a labial stop together with $/ \mathrm{a} /$, it is possible to argue that Nyong and Perema have preserved the CV suffix for human plural. Samba Leko lost the vowel, Maya and Sam lost the consonant, and the other Yendang languages lost both the consonant and the vowel, but possibly after the split from the Leko group. ${ }^{27}$

The second common feature seems to have structural character, namely that almost all languages of both groups have a human/nonhuman distinction for third person pronouns. However, the forms marking this distinction are different in these two groups.

It is worth noting that this article is just the very first step in analyzing plurality in some groups of Adamawa languages. The analysis should be supported by much more data from the languages of Leko and Yendang groups and comparative data from other groups of Adamawa languages.

\section{Acknowledgements}

I am very grateful to anonymous reviewers and editors of the issue for valuable comments and critics.

\section{Appendix 1 \\ Languages of Eastern Nigeria (Lewis et al. 2014)}

Languages under consideration are: Nyong - 284, Samba Leko 294, Bali (Maya) - 276, Yendang — 291, Kugama - 290, Waka 282, Kpasham (Sam) - 278.

${ }^{27}$ It is worth noting that this scenario is just a very preliminary possible hypothesis. 


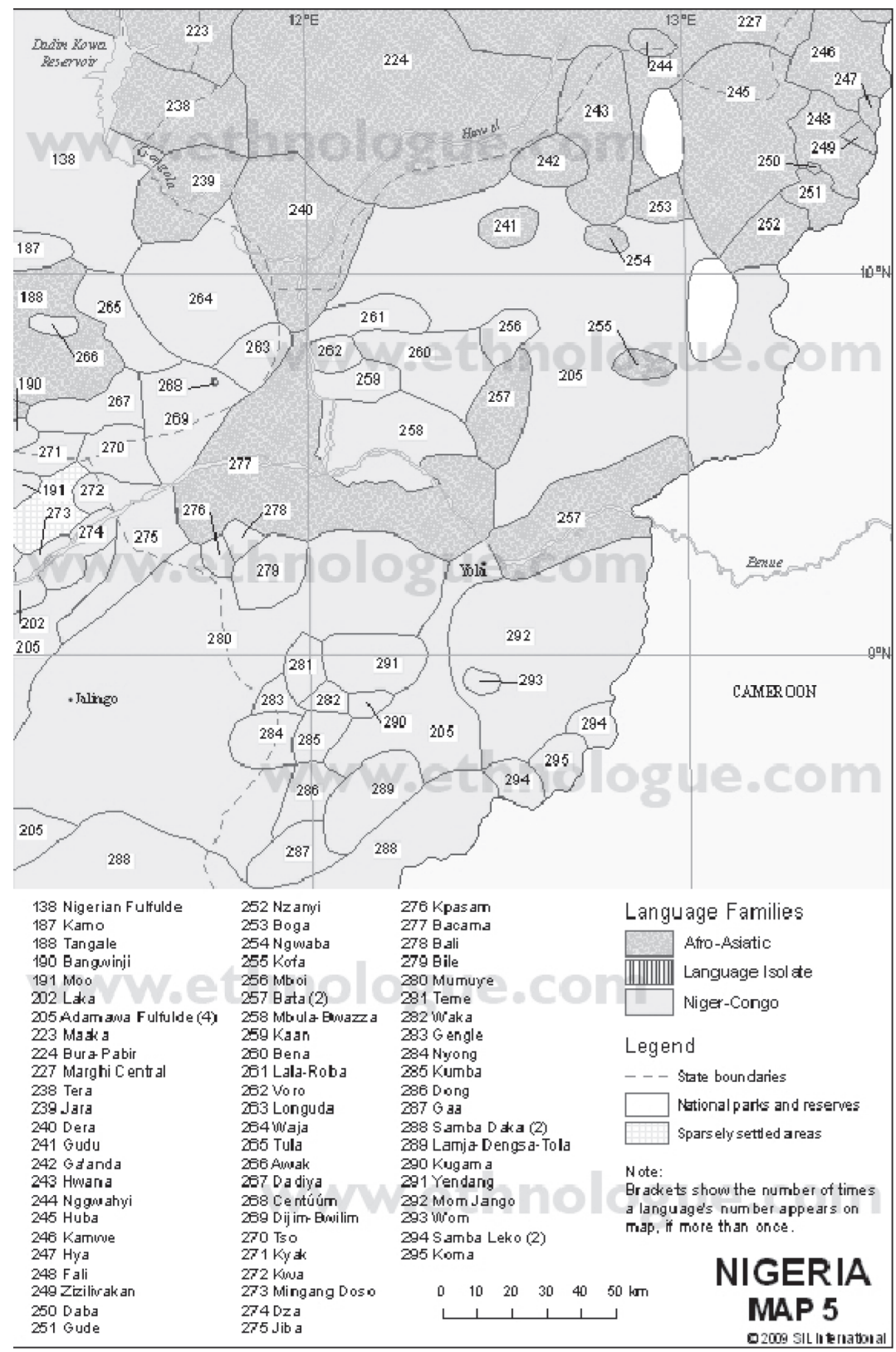




\section{Appendix 2 \\ Classification of Central Adamawa \\ (Hammarström et al. 2019)}

Languages under consideration are underlined.

V Central Adamawa (29)

$\nabla$ Mumuye-Yandang (11)

Gengle-Kugama

Kumba

Mumuyic (3)

$\nabla$ Yandang (6)

$\nabla$ Bali-Kpasam (3)

Bali (Nigeria)

$\underline{\text { Kpasam }}$

Yotti

$\nabla$ Waka-Yendang-Teme (3)

Teme

$\nabla$ Waka-Yandang (2)

Waka

$>$ Yendang

$\nabla$ Samba Duru (18)

Northern Samba Duru (7)

จ Southern Samba Duru (9)

$>$ Diic (3)

Longto

$\checkmark$ Peere

$\nabla$ Sambaic (4)

Kolbila

จ Samba-Leko-Perema-Mumbake (3)

$\checkmark$ Perema-Mumbake (2)

Nyong

Wom (Nigeria)

Samba Leko 


\section{References}

Anikina, Tatyana. 2012. Materialy k opisaniju morfosintaksisa jazyka jendang. [Materials for the description of the Yendang language.] In Zheltov, Alexander \& Vydrin, Valentin (eds.), Meždu Nigerom i Kongo. K 60-letiju Konstantina Pozdnjakova, 5-56. St. Petersburg: NestorIstorija.

Bennet, Patrick R. 1983. Adamawa-Eastern: problems and prospects. In Dihoff, Ivan R. (ed.), Current approaches to African linguistics. Vol. 1), 23-47. Dordrecht: Foris.

Blench, Roger. 2000. The Perema (Wom) language of northeastern Nigeria: classification, phonology and noun morphology. Manuscript. http:/ www.rogerblench.info/Language/Niger-Congo/AU/WOMonly.pdf (Accessed 2020-02-25.)

Blench, Roger. 2004. The Adamawa languages. Manuscript. http://www. rogerblench.info/Language/Niger-Congo/Adamawa/Adamawa\%20 language \%20list.pdf (Accessed 2013-06-30.)

Blench, Roger. 2009. The Maya [Yendang] languages wordlists: Collected by Barau Kato and Zachariah Yoder, analysis by Roger Blench. Manuscript. http://www.rogerblench.info/Language/Niger-Congo/AU/ Yandang\%20group/Comparatie\%20Yandang.pdf (Accessed 2015-0410.)

Blench, Roger. 2012. Niger-Congo: an alternative view. Manuscript. http:// www.rogerblench.info/Language/Niger-Congo/General/NigerCongo\%20an\%20alternative\%20view.pdf (Accessed 2020-02-05.)

Blench, Roger. 2020. The Adamawa languages: a consolidated list and classification. Manuscript. https://www.academia.edu/43166051/ The_Adamawa_languages_a_consolidated_list_and_classification (Accessed 2020-06-01.)

Boyd, Raymond. 1989. Adamawa-Ubangi. In Bendor-Samuel, John \& Hartell, Rhonda L. (eds.), The Niger-Congo languages: A classification and description of Africa's largest language family, 178-215. Lanham, MD: University Press of America.

Corbett, Greville G. 2000. Number. Cambridge: Cambridge University Press.

de Wolf, Paul. 1971. The noun-class system of Proto-Benue-Congo. The Hague: Mouton. (Janua Linguarum. Series Practica 167.) 
Dryer, Mathew S. 2013. Coding of Nominal Plurality. In Dryer, Matthew S. \& Haspelmath, Martin (eds.), The world atlas of language structures online. Leipzig: Max Planck Institute for Evolutionary Anthropology. (http://wals.info/chapter/33) (Accessed on 2020-06-18.)

Elders, Stefan. 2000. Grammaire mundang. Leiden: Research School of Asian, African, and Amerindian Studies, Universiteit Leiden.

Fabre, Gwenaëlle. 2004. Le samba leko, langue Adamawa du Cameroun. München: Lincom Europa.

Foley, William A. 1986. The Papuan languages of New Guinea. Cambridge: Cambridge University Press.

Greenberg, Joseph. 1963. The languages of Africa. Bloomington: Indiana University Press.

A Guide prepared at the Maya orthography workshop. 2007. Bali: Maya Language Development Board.

Güldemann, Tom. 2018. Historical linguistics and genealogical language classification in Africa. In Güldemann, Tom (ed.), The languages and linguistics of Africa, 58-444. Berlin: Mouton de Gruyter. (The World of Linguistics series 11.)

Hammarström, Harald \& Forkel, Robert \& Haspelmath, Martin. 2019. Glottolog 4.1. Jena: Max Planck Institute for the Science of Human History. (http://glottolog.org)

Kleinewillinghöfer, Ulrich. 1992 (2014). Evidence of noun classes in languages of the Yungur (Bəna-Mboi) group. https://www.blogs.unimainz.de/fb07-adamawa/files/2012/02/Evidence-of-noun-classes-inlanguages-of-the-Yungur-group.pdf (Accessed on 2020-06-16.)

Kleinewillinghöfer, Ulrich. 2019. Adamawa Language Groups. Adamawa Languages Project. https://www.blogs.uni-mainz.de/fb07-adamawa/ adamawa-languages/ (Accessed on 2020-02-05.)

Kouonang, Alice. 1983. Esquisse phonologique du parler bali-kumbat. Yaoundé: Université de Yaoundé. (M.A. thesis.)

Lewis, M. Paul \& Simons, Gary F. \& Fennig, Charles D. (eds.). 2014. Ethnologue: Languages of the world. $17^{\text {th }}$ edition. Dallas, Texas: SIL International. Online version: http:/www.ethnologue.com/subgroups/ adamawa-ubangi (Accessed on 2015-04-10.)

Litvinova, Lora. 2016. Elementy morfosintaksisa jazyka kugama [Topics in Kugama morphosyntax]. St. Petersburg: St. Petersburg State Uni- 
versity. (M.A. thesis.) http://llacan.vjf.cnrs.fr/AdaGram/publications/ WAM_Morphosyntax_LITVINOVA\%202016_MA_thesis.pdf (Accessed on 2020-02-05.)

Mel'čuk, Igor'. 1997. Kurs obščej morfologii [A course in general morphology]. Vol. 1. Moscow - Vienna: Progress \& Wiener Slavistischer Almanach.

Plungian, Vladimir. 2011. Vvedenie v grammatičeskuju semantiku. Grammatičeskie značenija $i$ grammatičeskie sistemy jazykov mira [Introduction to grammatical semantics. Grammatical meanings and grammatical systems of the languages of the world]. Moscow: RGGU.

Pozdniakov, Konstantin. 2015. Diachronie des classes nominales atlantiques. In: Creissels, Denis \& Pozdniakov, Konstantin (eds.), Les classes nominales dans les langues atlantiques, 57-102. Köln: Rüdiger Köppe Verlag.

Van de Velde, Mark \& Idiatov, Dmitry. 2017. Morphological classes and gender in Bəna-Yungur. In Kaji, Shigeki. Proceedings of the $8^{\text {th }}$ World Congress of African Linguistics, 53-65. Tokyo: Tokyo University of Foreign Studies. http://lacan.vjf.cnrs.fr/AdaGram/publications/BenaYungur Morphological Classes\%20 and Genders VAN DE VELDE_IDIATOV_2017_final.pdf (Accessed on 2020-09-30.)

Villa, Eveling. 2017. Pluralization strategies in Sam. Presentation at 47th Colloquim on African Languages and Linguistics (CALL) (Leiden, Netherlands). http://llacan.vjf.cnrs.fr/AdaGram/talks/SAM_2017 CALL_Leiden_Plural_VILLA_final.pdf (Accessed on 2020-05-02.)

Villa, Eveling. 2019. TAM system of Nyesam. Presentation at Workshop on TAM systems in Adamawa Languages (Hamburg, Germany). http:// llacan.vjf.cnrs.fr/AdaGram/talks/SAM_TAM_VILLA_2019_Hamburg. pdf (Accessed on 2020-05-02.)

Vydrin, Valentin. 2017 Jazyk bamana [The Bamana language] In Vydrin, Valentin \& Mazurova, Julia \& Kibrik, Andrej \& Markus, Elena (eds.), Jazyki mira: Jazyki mande [Languages of the world. The Mande languages], 46-143. St. Petesburg: Nestor-Istorija.

Zheltov, Alexander. 2014. Elementy morfosintaksisa jazyka n'ong (adamaua, niger-kongo) [Topics in Nyong morphosyntax (Adamawa, NigerCongo)]. In Zheltov, Alexander (ed.), Antropologija $i$ lingvistika: Materialy peterburgskix èkspedicij $v$ Afriku [Anthropology and 
Linguistics: materials of expeditions to Africa], 130-140. St. Petersburg: Museum of Anthropology and Ethnography RAS.

Zheltov, Alexander. 2016. Elementy morfosintaksisa jazyka maja (adamaua, niger-kongo) [Topics in Maya morphosyntax (Adamawa, NigerCongo)]. In Vinogradov, Viktor et al. (eds.), Issledovanija po jazykam Afriki [Research in African languages]. Vol. 6, 81-89. Moscow: Ključ-S.

Received 11.03.2020. Received in revised form 18.06.2020. Accepted 04.08.2020 